International Journal of English Literature and Social Sciences
Vol-6, Issue-4; Jul-Aug, 2021

Peer-Reviewed Journal

\title{
The Post-War English Novel in Terms of Form and Theme
}

\author{
Dr. Wisam Hamid Lateef
}

Al-Turath University College, Iraq

Received: 03 Jul 2021; Received in revised form: 21 Jul 2021; Accepted: 02 Aug 2021; Available online: 13 Aug 2021

(C2021 The Author(s). Published by Infogain Publication. This is an open access article under the CC BY license

(https://creativecommons.org/licenses/by/4.0/).

\begin{abstract}
The purpose of this paper is to study the effects of the First World War on the fiction of the third decade of the twentieth century - 1921 to 1930 - the immediate period succeeding war, and how the writers presented in fictional form the total disorder that had been spelt both in the world of history and the mind of men. Further, It has been intended tracing how the 'novel form' disintegrated and the novel is no longer remained a novel in the traditional sense. This paper also details how the writers tried to achieve their goal in fictional form and why the novel demanded a form which would not recapture the full texture of the horror scenario but also present an illuminating exploration of the deeper levels of individual consciousness.
\end{abstract}

Keywords-The First World War, fiction, society, writer-cum-soldiers, disillusionment.

\section{INTRODUCTION}

Until the First World War, writers had, for the most part, contented themselves with themes and values familiar to the previous century. The majority continued to write as though theirs was the best of all possible worlds, because it was one in which 'progress' seemed assured. But, the Great War seemed to have produced an unbridgeable chasm between generations. The postwar literature was bound to reflect this chasm, this disorder, which was a sequel to the war, engulfing the whole of Europe. Henceforth, the new writers and artists breathed in an air of cultural and moral disintegration. The pervasive feeling then, certainly is that any material gains, due to the tremendous progress of science and technology in the nineteenth century, must be balanced against a perceptible spiritual loss; and it is this spiritual loss which has received the literary attention in the postwar world of the twentieth century. The writers with a meaning conveyed a doleful lesson and nearly all writers turned against their age. They repudiated it, as far as they could. Hence, fear and anxiety, horror and hysteria, anger and exhaustion, boredom and emptiness in the face of imminent death became the dominant theme of literature. It germinated from the notion that "Literature, according to historical convention reflects contemporary life and reveals the spirit."(Taylor, 1992:236)
Contemporary life in the postwar world reflected the breakdown of an established order as the will of the people had exhausted itself on the warfront and the spirit of the age is symbolized by 'inaction' and 'inertness'. Prior to the holocaust of 1914-1918, the people had strode into this great adventure (war) for glory but "the weariness, the fever and the fret of the war", "made men sit and hear each other groan", because the postwar world symbolized a world, "where youth grows pale, and spectre thin and dies", and "where but to think is to be full of sorrow".

The shift in attitudes towards war is obvious. Far from being "an affair of great marches", it forced the lacerated spirit of mankind to adventure this time into a journey into its "injured psyche" to analyze the futility of its action. The void so created could not be filled. This prompted D.H. Lawrence to say; "This place no good". Throughout the first decade of the twentieth century, there had been a literature of social criticism of which G.B. Shaw, H.G. Wells and Galsworthy were the chief exponents. Though these litterateurs were anxious to reform the world, they did not ever question the ultimate possibility of reform, nor postulate the inadequacy of man as an instrument for the good life, nor did they have any conception of a possible disruption of civilization. Reacting most virulently to this attitude of these writers 
Ifor Evans fixes the responsibility for the disruption of civilization (if it ever can be fixed on literary artists), I feel, on Shaw, Wells and Galsworthy when he says:

\section{Wells and Shaw sometimes questioned the inevitability of progress, but never during this earlier period did they explore this idea with any seriousness. Nor were any of them interested profoundly in the nature of human mind itself. (Evans, 1978:2)}

Shaw's characters were too frequently automata, whom he hired to deliver his own brilliant speeches. Wells portrayed characters which were poignant, irrational and inconsequent, but he never bothered to study their incongruities. Galsworthy always portrayed types as he was busy with the upper middleclass society whom he was satirizing. Ifor Evans further laments the negative role of these social critics; "One of the extraordinary phenomenon is that both Wells and Shaw lived on throughout the interwar period and kept themselves aware of the changing shape of the times...".(Evans, 1978:2) and still did not do anything constructive 'to warn' about the impending dangers of the tremendous progress that had been so registered after the Industrial Revolution. In fact, they had been propagating the eradication of evil human tendencies in the social context, under the influence of education and a civilized environment, replacing them by good ones. Sigmund Freud says:

$$
\begin{aligned}
& \text { Civilized society which } \\
& \text { demands good conduct and } \\
& \text { does not trouble itself about the } \\
& \text { instinctual basis of this conduct } \\
& \text { has thus won over to obedience } \\
& \text { a great many people who \&re } \\
& \text { not in this following their own } \\
& \text { natures. Encouraged by this } \\
& \text { success, society has allowed } \\
& \text { itself to be misled into } \\
& \text { tightening the moral standard } \\
& \text { to the greatest possible degree, } \\
& \text { and it has then forced its } \\
& \text { members into a yet greater } \\
& \text { estrangement from their } \\
& \text { instinctual disposition. They } \\
& \text { are consequently subject to an } \\
& \text { unceasing suppression of } \\
& \text { instinct, and the resulting } \\
& \text { tension betrays itself in the } \\
& \text { most remarkable phenomena of }
\end{aligned}
$$

reaction and compensation. In the domain of sexuality, where such suppression is most difficult to carry out, the result is seen in the reactive phenomena of neurotic disorders. Elsewhere the pressure of civilization brings in its train no pathological results it is true, but is shown in malformations of character, and in the perpetual readiness of the inhibited instincts to break through to satisfaction at any suitable opportunity. (Freud, 1991:71)

Thus, while trying to eradicate the social and human evils, these social critics (Shaw, Wells and Galsworthy) completely failed to study the nature of man which consists of instinctual impulses which are of an elementary nature, which are similar in all men and which aim at the satisfaction of certain primal needs. They failed to highlight the cruelties inherent in man and these ultimately carried the world over to destruction in the 1914-1918 conflagration. Furthermore, if these social critics were only alive to the social, cultural and political implications of the dangers so engineered by this tremendous progress, they would have with their vision, warded off the romantic conception of war into the realities of wars, thereby making people aware of the horror, the disaster and the destruction accompanying it.

\section{THE WAR WRITERS}

Since the writers of the age were affected by the new human experience of the Great War, all were under compulsion to report, to inform and to warn the world about the impending dangers of yet another war. Therefore, it demanded a realistic portrayal of the horrors of war in fiction. But the larger audience of fiction demanded, in those years immediately after the war, any theme rather than that of the great conflict and its horrors because the general public was not prepared to face the realistic presentation of war in fiction. The dominant tendency of the readers was to forget the evil and brutality in reassuring itself that life was more kindly than the four years of wars had suggested. This desire to regain the illusion that they were civilized people, prompted them to give acceptance to A. S. M. Hutchinson's If Winter Comes, which was praised at the time for its high ethical quality, power and beauty. It was commended as the year's most arresting achievement in fiction. (Taylor, 1992:390) 
In other writers of the period, the underlying mood was sentimental. The Constant Nymph by Margaret Kennedy was about the day-dreaming of an adolescent girl. The Green Hat by Michael Arlen was even more unreal. It was the deliberate fabrication of a hard headed Armenian. It was solemnly accepted by social critics as a picture of contemporary manners. Furthermore, the nightmare of the Great War had inculcated in the people the spirit of escapism. The individuals sought more relief in the adventure stories contained in the novels of P.G. Wodehouse and Agatha Christie.(Taylor, 1992:391) She was accorded a rousing welcome to the literary scene. Her detective stories were Thrillers, as they had the sedative effects on the broken spirit of man. More of a social document, the detective story, in its sober, solid narrative, provided the ordinary people with more extra-ordinary experience.

Later on, the Englishman developed a taste for public entertainments which he pursued very religiously. They ignored the state of the world and the condition of human nature; yet with all its limitations, it was the desire for a kindlier world and a belief that man would be worthy of a finer life, if only his leaders and rulers would give him the chance. This resulted in glittering cinema houses going up everywhere, even in the most impoverished areas. Still photography and motion pictures, whose basic principles had been developed in the previous century, became major vehicles of expression following the First World War. Photographers and film directors explored the unique qualities of their media in pursuit of new and vivid ways of seeing. In 1927, when an American film producer was able to synchronize sound track with the pictures, the break from the realistic world was almost complete. True photoreportage had begun in the mid 1920's,(Wall Bank, 1978:867) when improved equipment and technical facilities enabled fleeting expressions and movements to be caught under varying lighting conditions. The film became the most popular and universal art form of the century. While most movies were made and watched for entertainment, the medium lent itself to the visual description of relationships and issues in contemporary society. Hence, the innovation of documentary films and, of course, social commentaries and satire by numerous actors, Charlie Chaplin, the most prominent of them.

Somehow, the belief still existed among ordinary men, that the suffering of the individuals had been so profound that its repetition was unthinkable. Perhaps these counts for the hostile reaction to the war books accorded by the public as well as by the fourth estate. The newspapers began to debunk not only the war books, but also the soldiers who had conducted themselves creditably at the warfront. Hardly was the nightmare at the warfront over, when they and their actions in the war came under severe censure at home. They were hurt. The earlier cynosures of the public during the war, came to be censured and condemned. This lacerated their sensibilities. Gradually, they came to brood over the futility of their action and finally inferred that they had been sold. This developed in them a mood of despair, and alienation and expressed itself in war books, the best example being Richard Aldington's Death of a Hero.

The novelist must have the leisure to exercise his craft to represent the human situation. It was in 1930's that large popular audiences, for the first time, were ready to reconsider the realities of 1914-1918 War as a theme for fiction. It became possible because, "perhaps English people were dreaming less. Perhaps they were trying to catch up with that was going on round them. More probably, the writers changed and not the readers." (Taylor, 1992:390)

In fiction, more than in any other form of literature, the writer finds a free and full scope to link the general fate of man to the fate of specific individual characters to illuminate it. Fictional art is more suited to this because the prose narrative takes in part the tradition of the great epics and thus not only recreates historical events and states of society, but also the dominant mood of alienation and despair which permeates individual psyche in an age of crisis.

This desire to consider the realities of war as a theme for fiction resulted in the exploration of the individual psyche with all its trails and turbulences, through which an individual had gone in the war. Therefore, the novelist, though remaining busy with his social preoccupations, returns to study the nature of man. The literary artist, from now on, would not only explore the causes leading to disruption of civilization, but would at the same time, explore the unconscious psyche of individual men and women - study the dark side of human mind. This change in attitude of the public came due to the study of social sciences and psychology which had come to play an important active role in the lives of the people. This led people to pursue another field of study - the study of human mind. It resulted in insights into man's conduct and his emotional life. Deriving from Freud's theory of Biological Instincts, a great emphasis was placed over the powers of unconscious to affect the conduct of an individual.

Freud's emphasis upon the unconscious and irrational states of human mind made a strong impact on writers and artists alike. Furthermore, a lot of importance was attached to Freud's concept of infantile sexuality Libido. Thus, it was through this theory of Biological 
Instincts that the novelists gained a new insight into the unexplored psyche of the individual in the following contexts:

1. That conscious life was only a small part of man's existence.

2. Mind, instead of being ordered and logical was like a disordered and misbehaved menagerie.

3. That sex played a far larger part in man's life. The writers were encouraged to be both very vocal and frank in the description of sexual experiences and henceforth, were less affronted by sexual abnormalities.

4. It also gave the vital clue that human relationships were now based on adjustments and readjustments.(Freud,1991)

Consequently, in the 1920's, there emerged the writers, the realists, who saw the sub-conscious mind as a vehicle that could free man from the shackles of modern society and lead him to freedom. They felt an affinity with primitive art and its close associations with magical and mythological themes and they exalted the irrational and the violent in human experience. Meanwhile, from a different perspective, the Cubists continued to expand their influences. Abstract, non-representational painting was taken up by young artists all over the world - except in the Soviet Union, where initial experimentation was aborted by ideological insistence upon socialist realism. The interwar years saw Picasso modify his Cubist style. He developed a neo-classical style in the 1920's., while in the next decade he painted his famous Guernica mural, vividly depicting the destruction of a small Spanish town by fascist air forces in that country's civil war. This painting combines artistic autonomy with a direct relationship to contemporary world events.

In literature, the emphasis on psychoanalysis led to the study of human personality and also brought to light the cruelty and evil inherent in the nature of man. This is amply demonstrated in the works of James Joyce, Virginia Woolf, D.H. Lawrence and T.S. Eliot. Initially these writers were condemned for being difficult, for not being intelligible to the reading public. Reflecting on Ulysses, Arnold Bennett became the spokesman for the general public, when he said that with Ulysses, the art of novel reading has become a form of penal servitude? E.M. Forster was more ironic and vociferous. He said that no one understood Ulysses, not even the police who prohibited its circulation.(Evan,1978:21)

In fact, this showed that there was an unbridgeable chasm between the writer and the reading public. There was no easy communication between society and the artist; hence there was no conception of a homogeneous community. In Ulysses, James Joyce was trying to discover some form, in which the modern consciousness in all its disruption and fragmentation could be represented. The past from which he departed was so compact and consolidated that his rupture from it left him lacerated and beyond the hope of complete recovery. Therefore, he looked upon the past with strange mixture of nostalgia and contempt.

\section{THE FICTIONAL FORM}

Henceforth, the question of form became one of the basic concerns of literary criticism. War which signified a crisis in civilization demanded a new fictional form which will not only detail the causal complexes of sociopolitical situation but will also explore the consciousness of individuals under the horrifying impact of dreadful events unleashed by war. The old patterns would not suffice, naturalistic emphasis on the merely documentary aspect of life would not do- The novel demanded a form which would recapture not only the full texture of the horror scenario but also present an illuminating exploration of the deeper levels of individual consciousness. The new novel must of necessity yield a dark and disturbing insight which cannot be related to any of the beliefs or rules which make' human societies possible.

The modern novelist, therefore, found the traditional form beset with grave limitations. The new reality could not be objectified through a hero-centered compact plot because the social life in the postwar world presented a bewildering spectacle of disintegration and moral vacuity. Defining the nature of life which the novelist seeks to translate into art, Elizabeth Drew says:

Life never builds itself into the convenient symme.try of a plot. Life is the quality of the immediate present as we live it from moment to moment. Experience is made from the silt of innumerable instants of consciousness, fusing the present with the memories of the past; blending thought and action and sensation; expanding into the widest contemplation of the human situation in its universal aspects or contracting into the observation of some small objects around us, or into fragments of talk, gestures, some fleeting association. It's all discontinuous, inconclusive, 
fugitive, flickering. This, at

last, is life.(Drew, 1969:17)

According to Holger Klein "fiction here had an immediate factual correlative of which millions were intensely aware."(Klein, 1978:4)The overriding criterion applied to war fiction is not merely one of verisimilitude, but moral truths as well. Henry James, too, lays it down as a prerequisite for writing a novel. He says, "The only condition that I can think of attaching to the composition of a novel is...that it be sincere."(Hazell, 1998:17) Thus it becomes imperative for the writer to assiduously scrutinize the correctness of detail and accuracy of data. This is necessary to achieve objectivity in detailing, the politicosocio-state of society and the historical forces operating underneath. However, mere documentation, howsoever comprehensive, does not make any war novel a work of art. No doubt, the central interest in the war novels lays not so much in the aesthetic philosophical question as such, but in the political implications. The principal aesthetic question is whether all this material has been structured into a literary form which has an enduring aesthetic appeal for the reader. A war novel has to be judged by the same criteria and methods of assessment which are applicable to all other forms of fiction.

The basic problem of composition in war fiction is "how to link the general fate to the fate of particular characters illuminating it."(Klein,1978:9) The majority of works achieve it by the demonstration of the impact of war on essentially anonymous, private, but representative individuals, or, small groups, and the concentration on impact rather than events, enables them to make the common soldier, a figure occupying an accidental and peripheral position in the war as history, a figure occupying an essential and central position in war as fiction. The most outstanding examples that can be cited are those of Christopher Tietjens in Parade's End and Ulysses in Ulysses. Ford Madox Ford in Parade's End directs the whole novel sequence at one individual Christopher Tietjens, who enacts all history, through his experience in the battlefield, his sufferings at the hands of his immediate superiors as well as his lawful wife - Sylvia, his close friend Macmaster to whom he was all help, thereby, exposing the change that had crept in because of the crumbling of the old order. Whereas the action in Parade's End is externalized, the action in Ulysses is confined to the labyrinthine realms of inner being of the central character. In other words, war is not treated as it is done by books of history, but in terms of its impact on the deeper layers of human psyche. In other words, in terms of everyman's experience of torment, boredom aloneness and anguish, the permanence of appeal of any war novel does not lie merely in the comprehensive delineation of the social state, but in how it is presented.

To do all this, the old forms of the novel do not suffice because the new cynicism cannot cope with them. Therefore, we notice a fracturing of form in Lawrence, Joyce, Virginia Woolf and others. The novel no longer now remained a novel in the traditional sense. Cyril Connolly holds Flaubert, Henry James, Proust and Virginia Woolf responsible having "finished off the novel". Alberto Moravia goes a step further to accuse these writers of being "the gravediggers of the nineteenth century novel.”(Bergonzi, 1979:14)

In fact, the traditional novelists of the nineteenth century, in their endeavor to present a unified vision of social life, deliberately turned a blind eye to the sordid and repellent aspects of their social environment. But the modern novelists with their unflinching loyalty to truth, busied themselves in projecting the socio-cultural disintegration in postwar society through the medium of their fictional art. The tradition of form of the novel was by no means a rigid mould capable of holding widely different varieties of facts about life. If life was dynamic, art too was equally dynamic and because of its close correspondence with life, it had, of necessity, to undergo alternation in order to meet the new kind of challenge that life posed from time to time. According to C.S. Ferns: "As a form the Novel evolved to deal with a world that was changing more rapidly than ever before, and it was perhaps to its very looseness and flexibility that it owed its success..." (Ferns, 1992:9)

The accelerating pace of the changes in the world, due to the advancement of science and technology, gave new freedom to the bourgeoisie. It was a period of "emancipated modes of an urge to freer behavior and preoccupation with personal styles and fashions, an appeal to the temporary, the hedonistic and the sensational." Because the novel provided "a way of responding to the world that was timeless and absolute", in the Laurentian sense, the novel therefore: “...is assumed to be intimately related with the rise of the bourgeoisie, with its generally individualistic view of life and other associated values..." (Hazell, 1998:26)But, it is not the exterior crisis that prompts an artist or shapes his art. He is no more interested in the materialistic presentation of the material in his art or "with the revolution in the world, but... he is concerned with revolution in the word".(Ferns, 1992:9)

Enlisting the essential difference between prewar and postwar novelists, C.S. Ferns states:

The difference, however, is that it is not asocial totality which they seek to portray, but 


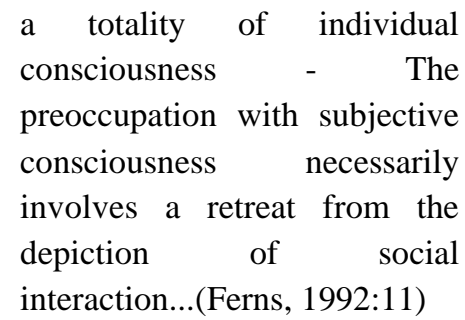

In an age when the disruption of civilization was taking place as a sequel to the Great War, and when society was faced with its fragmentation, the artist was led into strange paths. Since the Great War, the novelistic art has been under constant experimentation with regard to new fictional techniques and procedures, such as the control of the point of view, so as to minimize the apparent role of the author-narrator. The use of symbolist and expressionist techniques and of devices adopted from the art of cinema, the dislocation of time sequence, the adaptation of forms and motifs from myths and dreams and the exploitation of the stream of consciousness technique in a way that converts the narrative of the outer action and events into a drama of the life of the mind are all expressions of this. This experimentation has prompted the novelists to leave out such standard novelistic elements as plot, characterization, descriptions of states of mind and normal relation of time and space.

In the multivolume Remembrance of Things Past Marcel Proust explored psychological time, human relationships and his own perceptions and mental processes by means of the stream of consciousness technique. This influential work recognized no lasting significance in the external world; one's consciousness alone remains real. Virginia Woolf urged the writers to register "the myriad impressions" that fall upon the mind in an incessant shower, to be honestly truthful. She says:

if a writer were a free man and not a slave, if he could write what he choose, not what he must, if he could base his work upon his feeling and not upon convention, there would be no plot, no comedy, no tragedy, no love interest of catastrophe in the accepted sense...Life is not a series of gig lamps symmetrically arranged; life is a luminous halo, a semitransparent -envelope surrounding us from the beginning of consciousness to the end.(Allen, 1984:344)
Consequently, there is deliberate indifference to the story element. No logical progression of the story remains possible because life is to be presented in totality - from moment to moment. This enables the novelist to present a total picture of life both in the present and the past, based on memories. David Daiches stresses the importance of memories:

We are memories, and to
describe us truthfully at any
given moment means to say
everything about our past.
Memory is no longer regarded
as a device for looking back on
what has been left behind, but
as an integral part of
consciousness and
personality.(Daiches, 2012:87)

Because of the fact that the whole human life has to be presented on a small scale in a limited tract of time and space, in a microcosm, this involves the problem of selection and significance. Employing this technique, Virginia Woolf concentrates on character rather than plot, eliminating description altogether. Characters she brings to life, not through a series of logically ordered incidents, but by touches of detail so that records of thought, association and influences to past and present along with her consciousness of time and movement can all be captured in this technique.

In Mrs. Dalloway, this is more explicit. Though the time covered by the external action occupies only twelve hours, from the morning when Mrs. Dalloway goes out to buy her flowers for her party, to the evening when the party is over, yet the psychological method permits the whole life to be shown in between. Her novel Jacob's Room is about war of 1914-1918,for the theme centers upon the life of Jacob from his childhood to his days in Cambridge and his youthful years to his death in the war. In To the Light House, Virginia Woolf confronts us with a group of characters in close relation to one another, so that the whole novel is a symbol of time, life and death, thereby minimizing action.

Time, therefore, no more remains historical or clock time. It becomes psychological, fluctuating backwards and forwards, with the inherent desire to probe the consciousness of the individual. Alain Robbe-Grillet very strongly advocates this handling of psychological time in the novels. "Why should we try to reconstitute time that belongs to clocks in a tale that is only concerned with human time? Isn't it wiser to think of our memory which is never chronological?" (Bergonzi, 1979:27) This time-shift technique is employed by Ford Madox Ford in The Good 
Soldier, when the narrator unfolds his story in a piece-meal fashion, fragment by fragment, as his memories come back to him. Further the time-shift technique gives the novelist an opportunity to dramatize rather than describe the, worlds at play in the novel.

It results in bringing down the old barriers between the reader and the novelist's character. The novelist as a mediator almost disappears, whereas in the past, even James and Conrad figured as reporters or historians recreating a sequence of action in their novels,

As Ford puts it, "The object of the novelist is to keep the reader entirely oblivious of the fact that the author exists even of the fact that he is reading a book."(Allott, 1973:272)This absence or distancing of the narrator from the novel enables the novelist to record the impression of a moment during the course of the development of the action. Symbols provide the artist with a rich and powerful medium to objectify the complex and subtle realities of modern life.

All through the war novels, the action centers around one main character. This character is not a martial hero of the Renaissance or the middle ages. Consequently, he is not endowed with any heroic qualities which might make him a superman. He is a creature of this living world

'sodden red', with all the flaws and virtues. He is a person who symbolizes 'inaction' and 'inertness'. He very passionately suffers and is one to whom things happen rather than someone who imposes his will on life. Be the Ulysses of Ulysses, or George Winterbourne of Death of the

Hero or Christopher Tietjens of Parade's End or Theodore Gumbril Junior of Antic Hay, his heroism lies in passive suffering. It is a different case that George Winterbourne in Death of a Hero feels that the whole of the First World War was declared against his person, thereby viewing life and things from a single consciousness. It provides Richard Aldington an opportunity to condemn the prewar and the postwar worlds en bloc, whereas, according to D.H. Lawrence. "The business of art is to reveal the relations between man and his circumambient universe at the living moment".(Allen, 1984:56)

The methods of revealing rather than condemning the character as well as the types of the character revealed mark the greatest change in the art of the novel from its beginning to the present day. Instead of the traditional hero we have, "The anti-hero or the fool" (Daiches, 2012:108) who is isolated from his fellows and is seen struggling towards some individual fulfillment outside his own society. Birkin in Women in Love is one such glaring character of the postwar era. But, Lawrence in Women in Love and other novels has two special individuals, through whom he portrays the muddled state of the world. He makes one of them, Birkin, a figure of resurrection, suggesting what might lie beyond or that it could be a social recovery. David Daiches observes:

Lawrence had a powerful
original vision of life and that
this vision enabled him to use
the novel not as the guasi-
realistic social-cum-
psychological fable it had been
for so long but as a symbolic
and poetic presentation of the
underlining realities of
individual life and of human
relations
unquestionable.(Daiches,
2012:113)

Aldous Huxley goes a step further than D.H. Lawrence. His cast of characters is usually large enough to follow a multiplicity of stories, sometimes supplemented by stories within stories that recall the past. In fact Huxley attempts to portray the absolute truth in the most degrading form so that his prophetic vision shocks the sensibility of his readers. His characters are always seen mouthing his own ideas. These ideas have the widest possible range which is both serious and solemn and at times even heavy and absolute. This helps Huxley to expose the follies and frivolities of modern man comically. He neither satirizes nor condemns, but reveals these distortions in human beings to portray this absolute decadence in man. This gives rise to what Malcolm Bradbury calls "The Modern Comic Novel”.(Bradbury, 1984:140)

With this the traditional form of Novel disintegrates further. The form that Huxley uses is one of discussion or debate rather than the pleasing dialogue. We have ample evidence of this in Antic Hay. Those Barren leaves and Crome Yellow. Once again we find the traditional novel structure as an edifice of character and action crumbling and the narration slid into an essay or a pedagogic monologue. But all through the composition the underlying process is one of self-exploration and selfeducation, which according to Huxley shall help in the mitigation of human suffering.

E.M. Forster very aptly summarizes the modern novel in the following words, "Yes -oh dear yes - the novel tells a story. That is the fundamental aspect without which it could not exist. It runs like a backbone - or may I say, a tape-worm, for its beginning and end are arbitrary." (Forster, 2018:40) Perhaps this counts for the ending of AnticHay, wherein, the narrator says in the last line“" 
Tomorrow will be as awful as today". This indeed is a sad commentary on the state of affairs in the modern world.

\section{CONCLUSION}

The Great War resulted in a fractured culture. Consequently, humanity has been forced to live in a comparatively inferior and valueless society thereafter. The economic movement hastened the world towards war because it accelerated to an enormous speed bringing all sorts of changes into national and personal 1ife. No doubt the movement began about one hundred and fifty years ago, but it took the whole world in its fold right from agriculture to industry- Consequently machines came to be worshipped and valued because they conferred power and ensured material prosperity, thereby preventing abso1utedestitution.

The War took a heavy toll of human beings. It affected deeply the writers, as it did every one, in diverse ways. The horrors of war and the experience of these writer-cum-soldiers in battlefield made then decry the spirit of adventure which drove them to an alien soil- They began to introspect and question the utility of war. The brutalities of warfare in the form of gas attacks, trench warfare made the writers condemn the hypocritical attitude of their contemporaries in prose. Thus the attitudes changed and not the peop1e. In prose, the writer displayed unrest or disillusionment or anxiety which came to burden the minds of the people. As a result one of the main characteristics of the prose of the time was that it was the product of the people who had war on their mind

Simultaneously, it resulted in the fracturing of the traditional novel form, and the Aristotelian essentials such as plot, action, characterization etc. hold no good any longer. These were replaced by stories within stories and the action which earlier was external became internal.

The psychological time set in a cyclic movement of though and memory came to play a major role in this. Symbols came to provide different meanings. As the common man was the worst sufferer during the war days, his sufferings, agonies and anguish became the subjectmatter of the novelist, who would in turn translate them into fiction by selective ordering to hammer home the idea that if there were to be another war of the same magnitude as of The Great War, then humanity would be almost wiped out, as happened in the course of Second World War when Nagasaki and Hiroshima in Japan were completely destroyed. However, Lateef (2021) believes that "Men are often at war with each other in their efforts to glorify themselves."(p.30)

\section{REFERENCES}

[1] Allen, Walter. 1984. The English Novel. Middlesex: Penguin.

[2] Allott. Miriam1973. Novelists on the Novel. London: Routledge \& Kegan Paul.

[3] Bergonzi, Bernard. 1979. The Situation of The Novel. London: Macmillan.

[4] Bradbury, Malcolm1973. Possibilities: Essays on The State of The Novel. London: Oxford University Press.

[5] Daiches, David. 2012. The Present Age In British Literature. Literary Licensing, LLC.

[6] Drew, Elizabeth. 1969. The Novel: A Modern Guide to fifteen English Masterpieces. New York: Dell.

[7] Evans, B. Ifor. 1978. English Literature between the Wars. Norwood, Pa: Norwood Editions.

[8] Ferns,C. S. 1992. Aldous Huxley: Novelist. London: The Athlone Press.

[9] Forster, E. M. 2018. Aspects of the Novel. München: Rosetta Books.

[10] Freud, Sigmund. 1991. Freud Library 12 Civilization Society And Religion.UK: Penguin books.

[11] Hazell, Stephen. 1998. The English Novel: Developments in Criticism since Henry James. London: Macmillan.

[12] Klein, Holger. 1978. The First World War in Fiction. London: Macmillan.

[13] Taylor, A. J. 1992. English History, 1914-45. Oxford: Oxford University Press.

[14] WallBank, Taylor, Baikey, Jewsburry. 1978. Civilization Past and Present. Glen views: Scott Foresman \&Co.

[15] Wisam Hamid Lateef. (2021). Humanism in Norman Mailer's War Novels. Journal of Humanities and Education Development (JHED),3(4), 30-36. Retrieved from

https://www.theshillonga.com/index.php/jhed/article/view/ $\underline{226}$ 